\title{
THE EFFECT OF INFLUENCERS ON BUILDING RELATIONSHIPS WITH THE GROUP OF RECIPIENTS
}

\author{
URSZULA CHRACCHOL-BARCZYK
}

University of Szczecin, Faculty of Management and Economics of Services, POLAND

e-mail: urszula.chrachol@wzieu.pl

\author{
\begin{tabular}{l|l} 
RECEIVED & 1 May 2018
\end{tabular} \\ ACCEPTED $\quad 1$ September 2018 \\ JEL \\ CLASSIFICATION \\ L82, L86, M31
}

KEYWORDS marketing, relationship building, influencer

ABSTRACT Influeners are becoming an increasingly popular communication tool thanks to which a company can gain a lot. Influencer, by being authentic, builds strong relationships with the group of its recipients. Companies that invite such people to their campaigns may influence the increase of sales volume, increase of brand recognition, and the involvement of consumers in the company's activities. However, choosing an influencer is not a simple task. The article presents the definition of the influencer concept, activities to be performed by selecting an influencer and examples on the Polish market of the use of influencers in company activities. The aim of the article is to show that influencers can be an effective tool of communication between a company and a group of consumers, and influence the building of relationships.

\section{Introduction}

Influencers are a popular trend in marketing communication. Their number has been systematically growing for a few years. This is also reflected in the business marketing companies, which more often cooperate with bloggers, vloggers or profile owners in other social media. 
This trend also affected the emergence of the concept of Influencer marketing, which is defined as the field of marketing based on the recognition and position of people involved in the promotion. It is reminiscent of recommendation marketing, however, it focuses only on the opinions of influential Internet users (Knowledge base).

Increasing importance of influencers is confirmed by the results of research, which show that over $53 \%$ of buyers declare that the decision to buy the product was taken under the influence of the person they are watching in social media. Internet users often consider vloggers to be experts in a given field. Their recommendations and the ability to discuss and comment, make publications about brands on vlogs more reliable for them than traditional advertising on TV, radio, press or on billboards. The marketing industry began to cooperate with infuencers due to the relatively low cost of building coverage. Today, many top companies are able to pay very much for the top creators. In the US, already $65 \%$ of companies use influencer marketing in their communication. In Poland, this market is still young. The number of ads and expenditures on them are growing at a slower pace than the amount of content, but more and more brands are aware that thanks to cooperation with creators, they can reach specific target groups more effectively. However, many companies still do not know how such cooperation should look like. There is no belief in influencer ideas (Nowak, 2017).

\section{Influencers - who are they?}

Influencer is a person who has a strong influence on their recipients - their views, opinions, shopping habits. The distinguishing feature of someone like this from any other person, which could also be said that he or she affect others, is building relationships with their recipients.

An influencer should be a person who owns a blog, a vlog, an account on Youtube, Snapchat or other Social Media and may influence the opinion of at least a few hundred people (Kawalec, 2016) Not always influencer is a specialist in the field in he or she comments. The second group of influencers are public figures - celebrities, artists, athletes, politicians, etc., whose reach is often larger than people known for running a blog.

Influeners are not a homogeneous group and they can be divided depending on the number of users who follow the profile of a given person in the social network (Makuch, 2018):

- microinfluencers (from 1,000 to 100,000 followers),

- mid-tier influencers (from 100,000 to, 1,000,000 followers),

- top-tier influencers (over 1,000,000 followers).

Thanks to cooperation with brands, influencer can transform your passion into regular work. However, it is not enough to have a good idea for interesting content, especially if the creator is working on the YouTube channel. The traffic on the channel depends on many factors. The appropriate title, description and also watch-time (time of watching the material) or presence in the tab 'recommended'. The technological aspect is important. You need to skillfully use all the functions and rules that affect the result of the channel, that is its subscription (Nowak, 2017).

Forms of cooperation with influencers are various: product placement in their program, testing and product review, special episode dedicated to the product, organization of competitions with a given product, participation in brand mobilization in social media, advertising spots, press.

Influencers very often show exaggerated images of themselves, e.g. women, who 3 weeks after the birth of a child returned to the former figure and show themselves in pictures in full make-up. By contrast, by showing 
different hardships, such as tiredness after training, and not perfection at any time, you can build with the fans much more understanding and trust.

In many cases, consumers trust in smaller influencers than the top ones. The strength of microinfluencers lies in their naturalness, authenticity and commitment. They are often perceived as "people from the neighborhood", they give the impression that interneters know them personally, which translates into credibility and lasting relationships with a group of recipients. This makes their content more effective than traditional advertising. The average level of generated involvement under the posts by microinfluencers of inda Hash is even 5 times higher than in influencers with large ranges. By engaging several microinfluencers, you can get the same range as the woth toptier influencers, getting a higher commitment rate (Makuch, 2018).

The group of recipients called digital natives, constantly connected to the network, is bombarded every day with advertising messages and remains insensitive to artificial communications, therefore authenticity matters much more. There are influencers who understand this. In the group of parenting bloggers also honesty is more and more in price, much more than the photos of equally arranged blankets, as seen on the example of Maia Bohosiewicz, who on her Instagram account shows motherhood without icing or on the blog nostressbeauty, where Maria Kowalczyk does not use artificial embellishments, despite that the blog is about beauty. Influencers, at least in principle, build their title influence on knowledge, sharing experiences, ideas or own creativity (Przybylski, 2017).

\section{Influencer's - how to choose them?}

First of all, the influencer should be matched related to the given brand. If someone has a clothing store, they should look for, for example, influencers who have nice pictures in the designs of the istagram. When choosing from among several known people, many indicators should be taken into account. First of all, in the network, especially on the websites of agencies that cooperate with influencers, there are rankings (Figure 1). They contain numerical data about the size of subscriptions and impressions as well as the increase in subscriptions on a daily, weekly and monthly basis. This is important, because the fact of having many subscribers does not guarantee the continuing popularity of a given person. Therefore, when analyzing the subscription growth, it is possible to check how many subscribers come on a regular basis and whether the given influencer still enjoys such a high popularity as for example a year before.

Secondly, an estimate of the influencer's reach requires data such as the number of fans on Facebook, Twitter subscribers, YouTube channel subscribers, as well as the number of page views and unique users on the website or blog. However, it is a mistake to perceive the creator of the internet through the prism of reach. The fact that an influencer has a wide audience does not mean that it is matched to the group of recipients of the product. Most companies do not appreciate smaller influencers because they think that one action with a large range is more effective. Meanwhile, cooperation with a larger group of smaller, in terms of reach, creators allows for achieving higher ROls. Such activities require more work, so it is good to run them through an agency that knows who to work with, both in the case of range advertising and content marketing (Nowak, 2017).

Depending on the specific social media one can ask about internal statistics, but it is also needed to check those visible ones. In the case of Facebook, it is the number of likes, the frequency of entries, the quantity and quality of comments under the entry, participation in other campaigns. YouTube is the number of subscribers per channel, the number of views of individual videos, the quantity and quality of comments under the video being displayed, and how the influencer responds to them. 


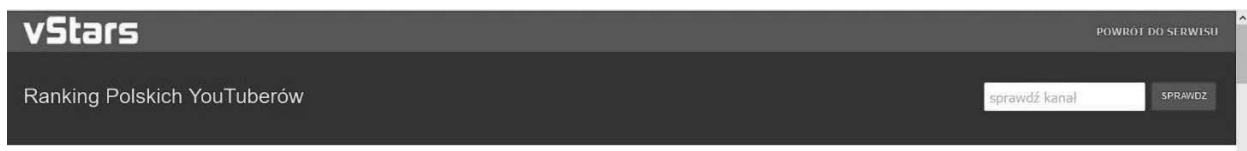

Ranking Wideo

\begin{tabular}{|c|c|c|c|c|c|c|c|}
\hline & \multirow{2}{*}{ kanal } & & \multirow{2}{*}{ subskrypcje } & \multirow{2}{*}{ wyświetlenia } & \multicolumn{3}{|c|}{ przyrost subskrypcji } \\
\hline & & & & & dzienny & tygodniowy & miatipany \\
\hline$\# 1$ & E Miasto Samochodów - Auta i Ciężarówki Bajki & & $137320 \quad 569$ & 150926422 & $284+$ & 1799 읍 & 137320 숩 \\
\hline$\# 2$ & = FIT LOVERS & & $751781 \quad 73$ & 90549766 & 3103 弇 & 24382 會 & 123263 슬 \\
\hline$\# 3$ & = Wojan & & $5 9 9 5 4 6 \longdiv { 1 0 2 }$ & 59222029 & 3146 술 & 18597 슬 & 105661 뜨 \\
\hline$\# 4$ & E Mniej Więcej & Q0 & $147459 \quad 558$ & 3540339 & 2956 늘 & 18411 䨔 & 101313 슴 \\
\hline$\# 5$ & $=$ tvnpl & tvn & $899579 \quad 57$ & 1283131673 & 2640 술 & 21808 숩 & 87355 울 \\
\hline$\# 6$ & E Bazylland & $\theta=0$ & 78543569 & 549391009 & 2622 숩 & 23514 숩 & 86067 술 \\
\hline$\# 7$ & - GURAL & & $234769 \quad 346$ & 3164980 & 580 争 & 7055 슘 & 86001 눌 \\
\hline
\end{tabular}

Figule 1. Ranking of influencers

Source: Ranking of Polish YouTubers http://ranking.vstars.pl/?sort=month_change\&.

The target group that the company wants to reach is also important. Then, one look at the demographic structure of the influencer's group of contributors and decide if it is consistent with the target group of the company. Table 1 contains information that should be analyzed when deciding to cooperate with influencers.

Table 1. Places to acquire data about influencers

\begin{tabular}{|c|c|}
\hline Tool & Description \\
\hline 1 & 2 \\
\hline Internet monitoring & $\begin{array}{l}\text { using the internet monitoring tools, e.g. Brand } 24 \text { or SentiOne, one can find people who often express their opinions } \\
\text { on topics related to a given product or service. Such research will also allow to follow how the statements of the } \\
\text { potential influencer are commented. }\end{array}$ \\
\hline Reports & $\begin{array}{l}\text { Sotrender's trend reports enable to see which channels on Youtube, FB fanpage, Instagram and Twitter profiles } \\
\text { were the most popular recently. }\end{array}$ \\
\hline Rankings & $\begin{array}{l}\text { both the companies and the influencers themselves undertake to create different types of rankings of bloggers, } \\
\text { youtubers, Instagram accounts, etc. The most popular ones are the review of the most influential bloggers of Jason } \\
\text { Hunt. Andrzej Tucholski also creates his ranking. Youtubers with the widest range can be found in the already } \\
\text { described vStars. }\end{array}$ \\
\hline Google search engine & $\begin{array}{l}\text { you can also search for influencers in Google. The easiest way is to enter a key phrase, e.g. "fashion blog", } \\
\text { "parenting blog", "culinary blog". Another way is to enter a specific phrase related to a given product. If you are } \\
\text { looking for a technology influencer, you can search for reviews of a particular phone model. In the top 10, a blog will } \\
\text { definitely appear. }\end{array}$ \\
\hline Instagram - similar profiles & $\begin{array}{l}\text { if you want to get involved with instagramers, you can find one whose profile meets expectations and start watching } \\
\text { it. A similar profile will appear over the profile, which is also related to the subject. }\end{array}$ \\
\hline Contests & $\begin{array}{l}\text { bloggers and youtubers can also be found among the winners of contests such as the annual Gala of Creators } \\
\text { (formerly Blog of the Year) or Grand Video Awards. }\end{array}$ \\
\hline Groups on facebook & $\begin{array}{l}\text { is a great place to look for microinfluencers as well as an unusual target group. For example, if you need to find } \\
\text { bloggers owning a cat, or youtuber, which will soon be getting married, you can post on a blog group (Blogs } \\
\text { - cooperation, interior design blogs) on influencer marketing (e.g. Influencer Polska - virtually on influencer } \\
\text { marketing). Bloggers and youtubers, not being the addressee of the query, will be happy to recommend their } \\
\text { friends. Microinfluencers can be found on industry groups. }\end{array}$ \\
\hline
\end{tabular}




\begin{tabular}{ll}
\hline \multicolumn{1}{c}{1} & \multicolumn{1}{c}{2} \\
\hline Platforms & the most convenient way to search for influencers is to use the platform grouping creators. For example, in the \\
& WhitePress platform, influencers can be searched by topics, tags and channels in social media. Profiles are also \\
& sorted by ranges and prices. You can immediately send an inquiry to the influencer and conveniently carry out the \\
& campaign without unnecessary e-mails and contracts. In the platform, you can easily find microinfluencers, who are \\
& often willing to square up in the form of barter. \\
they are an opportunity to establish relationships with influencers. It may be a typical blogging event like \\
Events
\end{tabular}

Source: Górecka (2017).

The involvement of the influencer in the brand campaign means primarily its credibility, increasing trust, reaching a new audience and tightening ties with them, thanks to the emotional relationship. However, for every marketer it is the conversion that matters, i.e. whether the user has decided to buy. During the campaign, the opinion leader may encourage participation in the competition, entry to the brand website, purchase for a voucher lowering the value of the basket. Giving an individual code, tagging the campaign will allow retargeting to people who have entered the brand's website. You can build their profile and send them a dedicated message at the right time and place. Thanks to performance marketing, the brand can measure the influence of the influencer on sales (Nowak, 2017).

\title{
Examples of campaigns with the involvement of influencers
}

In the network you can find numerous examples of influencers' involvement in promoting brands. Special articles and rankings of the best case studies are created, also with the divisions into industries.
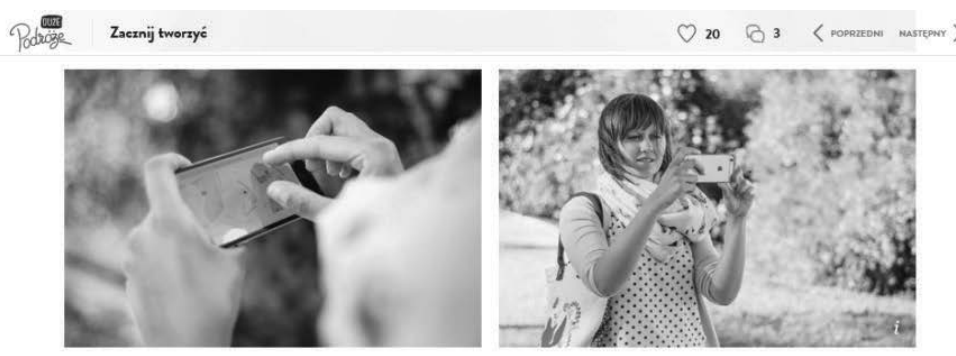

\begin{abstract}
Gdy wychodzę do centrum żeby przygotować nowy post, oprócz swojej lustrzanki mam ze sobą iPhone którym robię zdjęcia lub kręcę filmiki - świetny aparat, sterowanie ekspozycją $i$ bardzo prosta obshuga sprawiają, że przy zdjęciach nie trzeba wiele mysleć, wystarczy wczuć się w miasto i klikać. Aż mnie dziwi, że aparat w telefonie može być taki dobry. Gotowe zdjęcie obrabiam w aplikacji vSCO lub Enlight $i$ wrzucam na fanpage FB lub Instagram, którymi zarządzam głównie z telefonu.

Na iPhonie sprawdzam również i zapisuję ciekawe miejsca w TripAdvisor albo po prostu korzystam z map Apple.

Aplikacje:

VSCO Cam - aplikacja do przerabiania zdjęć z telefonu. Ma wbudowane filtry (ladniejsze niż te w lnstagramie), ale można teź nią ustalać cienie, jasności nasycenie fotografii $i$ kolory tonów.

Enlight - zaawansowana aplikacja do fotografii, umożliwiająca bardzo precyzyjną kontrolę nad zmianami które stosujemy. Opcji ma mnóstwo - od filtrów i presetów, przez nakladanie na siebie zdjẹć po tworzenie memów ze swoich foci. Ma teź najladniejsze logo, z lodowym lisem!
\end{abstract}

Figure 2. Post regarding the Apple phone on the Duże Podróże blog

Source: 10 campaigns... (2017). 
The author of the blog Duże Podróże has partnered with the Apple brand and the official distributor of its products on the Internet, iSpot.pl - she prepared for her readers a guide on the most useful applications available on iOS. Systematic publication is an extremely important issue for every blogger: even when Aleksandra is many thousands of kilometers from home, she can easily prepare new entries, process photos or edit movies (10 campaigns..., 2017).

Marta Muszyńska, the author of the blog Podróżniczo.pl, decided to give a few hints to her readers: she prepared the arrangements with Westwing, a brand dealing with interior design accessories. Scandinavian, American or French style - a travel atmosphere and a stylish finish guaranteed (10 campaigns..., 2017.
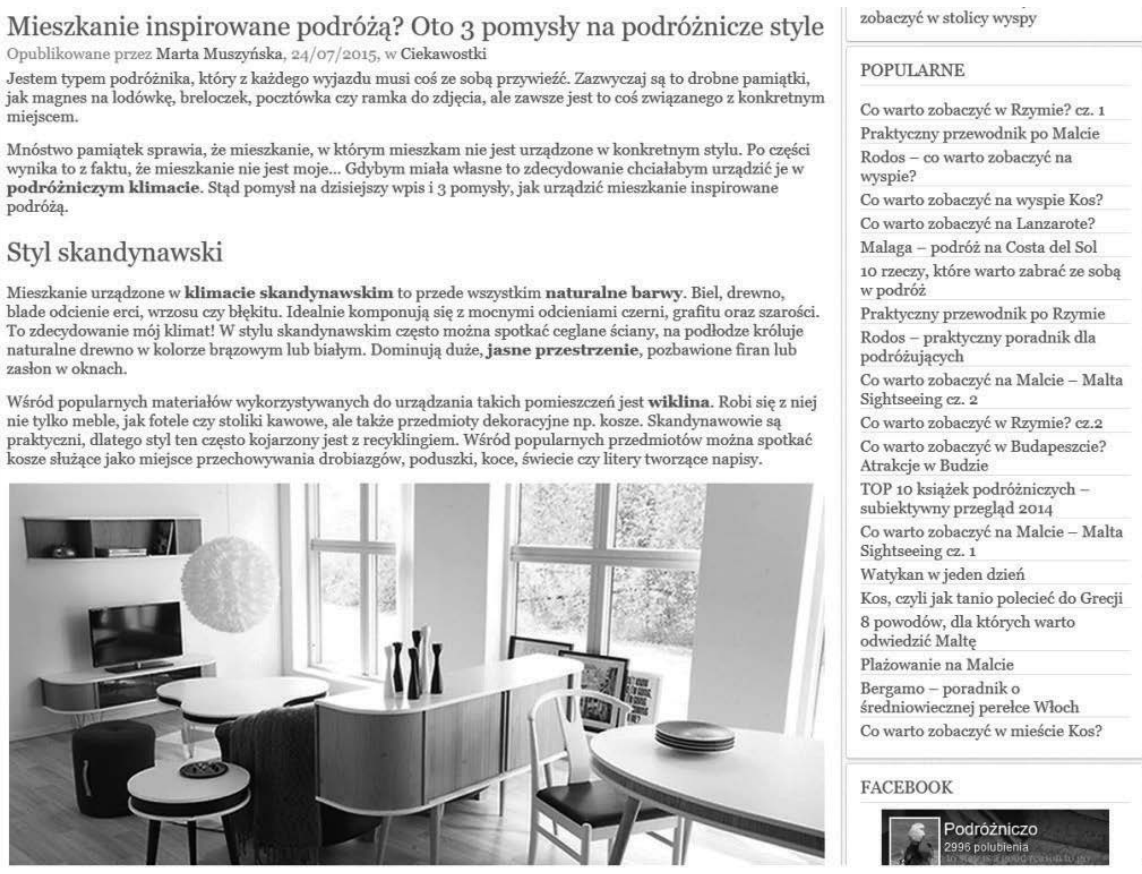

Figure 3. Post regarding interior design (Westwing brand) on the Podrózniczo blog

Source: 10 campaigns... (2017).

The Amica brand introduced a new blender to the market and decided to invite famous bloggers to cooperate. WyzwanieKoktajl campaign included Jessica Mercedes, Maciej Mazurek (Zuch Rysuje), Koszulkowo, Mediafun or Kocham Gotować - its aim was to involve them in creative promotion, dissemination of the supporting hashtag and gaining popularity in social media. The action definitely paid off: over 28 blogs were published, the brand gained new ambassadors and successfully promoted its new blender. In addition, the community involved actively exchanged the recipes for healthy cocktails (50 campaigns..., 2016).

Michał Szafrański, the author of the popular blog Jak oszczędzać pieniądze (How to save money) established one-year cooperation with MasterCard. As part of it, he prepared a compendia of knowledge about bank cards and the course "Defeat your debts". He shared his knowledge, advised, answered questions - that is, he did what 
he has done so far on his blog - thanks to which he gained many new readers, and the brand got a very good place for promotion. Also the lkea brand, on the occasion of the premiere of the new catalog, organized a photo session with bloggers, which then went on personalized covers. In addition, each of them described their day with the Swedish furniture brand, added photographs behind the scenes, and at the same time promoted lkea in social media. In action took part, e.g. Vanitas, Szafa Sztywniary or StayFly (50 campaigns..., 2016).

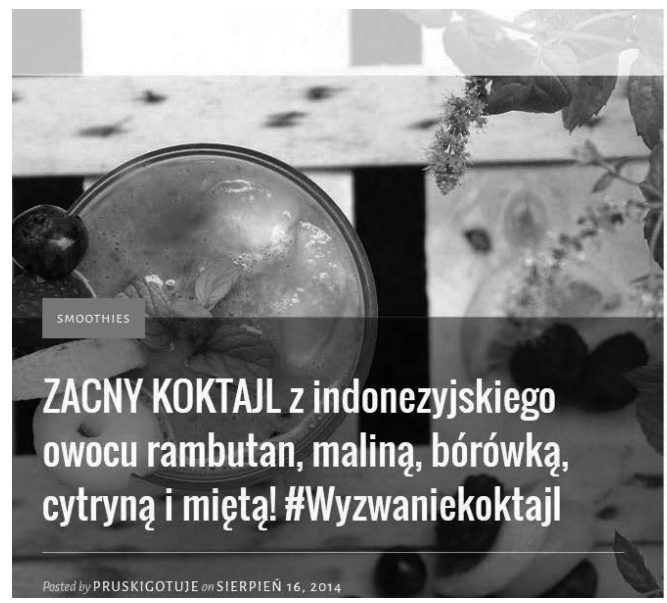

Figure 4. The Amica brand campaign on the Pruskigotuje blog
STRONA GLÓWNA WSPÓtPRACUJĘ Z ... O PRUSKIM OGRÓDW DOMU / LIFESTYLE

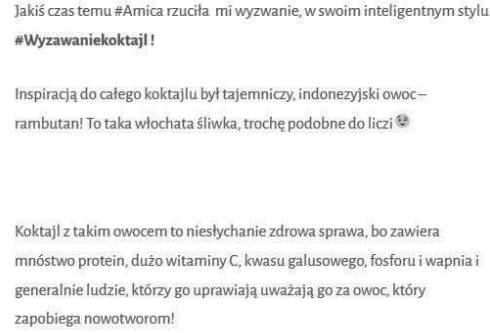

Jakiś czas temu \#Amica rzuciła mi wyzwanie, w swoim inteligentnym stylu

zapobiega nowotworom!

Source: 50 campaigns... (2016).

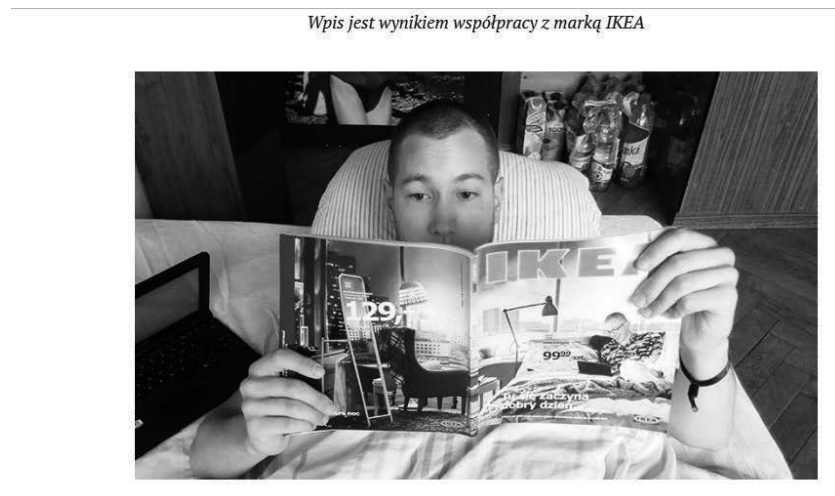

Jeszcze kilka miesięcy temu każdy mój dzień wyglądał tak samo i za bardzo nie różnił się od dnia kogokolwiek innego pracującego na etacie. Większość poniedziałków, wtorków, śród, czwartków i piątków wyglądała niemal identycznie. Sobót i niedziel w zasadzie też. No, chyba, że była Wielkanoc, Boże Narodzenie albo wypłata. Ewentualnie awaria internetu w firmie.
OAUTORZE

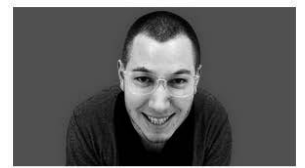

Mieszkam w Krakowie i jest zajebiście. Lubię dobre jedzenie, głośną muzykę, ciekawych ludzi i jazdę na rowerze. Nie lubię makaronizmów, disco polo i wiecznych malkontentów. Chodzę z głową w chmurach nie patrząc pod nogi. Każdego dnia potykam się o worek doświadczeń $i$ kontener marzeń. Pisząc bloga od jesieni 2011 roku spelniam to najwieklsze.
fl obserwuj Jan Fave ma 2507 obserwujacych.
Dotacz do ich grona przed swoimi Dotacz do ich grona przed swoimi

TWARZOKSIAŻKA

Figure 5. Ikea brand campaign on the StayFly blog

Source: 50 campaigns... (2016). 


\section{Conclusion}

Influencers have invaded the world of marketing communication tools for good and certainly this trend will continue to develop. Forecasts for 2018 indicate development in the microinfluencers group and that Instagram will have the largest number of campaigns using influencers. This is certainly influenced by the change in facebook policy regarding the reduction of organic ranges.

Watching different people online, using bloggers' advice influences building trust between the user/observer and the person running the medium. Through the authenticity of a person, the quality of his/her entries and opinions it becomes a pattern that influences the creation of opinions in others, and thus their purchasing behavior. In this process, the relationship between these parties is being built. As numerous research results show, consumers less and less trust television advertising, and they are more likely to believe in influencers. This is also reflected in the marketing activities of companies that are constantly trying to build relationships with groups of their buyers. The involvement of influencers for this purpose can help them, and it is important that it is a cheaper and more effective tool than many other campaigns massively used by companies.

\section{References}

10 campaign in the blogosphere. Travel industry (2017). Retrieved from: https://www.whitepress.pl/baza-wiedzy/425/10-kampaniiw-blogosferze-branza-podroznicza.

Knowledge base (2016). Retrieved from: https://www.whitepress.pl/baza-wiedzy/influencer-marketing.

Górecka, P. (2017). How to choose influencers - is only the range only important? Retrieved from: https://www.whitepress.pl/ baza-wiedzy/536/jak-wybrac-influencerow-\%E2\%80\%93-czy-liczy-sie-tylko-zasieg.

Kawalec, B. (2016). Kim jest Influencer? Po zasięgach i charyzmie ich poznacie. Retrieved from: https://www.whitepress.pl/ baza-wiedzy/275/kim-jest-influencer-po-zasiegach-i-charyzmie-ich-poznacie.

Nowak, J. (2017). Influence influencer. Like the YouTube stars, they make marketing for large companies. Retrieved from: https://www. forbes.pl/przywodztwo/influencer-marketing-influencerzy-i-youtuberzy-jako-narzedzie-marketingowe/zmbg0p5.

Przybylski, M. (2017). Influencers - between truth and creation. Retrieved from: http://www.proto.pl/wywiady/influencerzy-miedzyprawda-kreacja.

50 campaigns with digital influencers that have taken over the blogosphere (2016) Retrieved from: https://www.whitepress.pl/ baza-wiedzy/434/50-kampanii-z-udzialem-digital-influencerow-ktore-zawladnely-blogosfera.

Makuch, K. (2018). Microinfluences in advertising campaigns in 2018 - selection criteria, ideas for cooperation, settlement and measurement of effects. Social Media Manager, 1 (4).

Cite this article aS: Chrąchol-Barczyk, U. (2018). The effect of influencers on building relationships with the group of recipients. European Journal of Service Management, 3 (27/1), 23-30. DOI: 10.18276/ejsm.2018.27/1-03. 